\title{
Investigation on allelopathic effects of Khat leaves residues and alleviative effects of salicylic acid in wheat roots
}

\author{
Khalid Al-Mureish ${ }^{1}$, Abdulbasset Mohammed Ahmed Al-Hakimi ${ }^{1,}$, \\ Niyazi Abdulmawla Sallam Al-Areqi ${ }^{2}$, Elyas Sadeq Al-Aghbari ${ }^{2}$ \\ ${ }^{1}$ Department of Biology, Faculty of Applied Science, Taiz University, Taiz, Yemen \\ ${ }^{2}$ Department of Chemistry, Faculty of Applied Science, Taiz University, Taiz, Yemen
}

Email address:

alhakimi1969@yahoo.com (A. M. A. Al-Hakimi)

\section{To cite this article:}

Khalid Al-Mureish, Abdulbasset Mohammed Ahmed Al-Hakimi, Niyazi Abdulmawla Sallam Al-Areqi, Elyas Sadeq Al-Aghbari. Investigation on Allelopathic Effects of Khat Leaves Residues and Alleviative Effects of Salicylic Acid in Wheat Roots. Plant. Vol. 2, No. 5, 2014, pp. 54-59. doi: 10.11648/j.plant.20140205.11

\begin{abstract}
Allelopathic effects of khat leaves residues (25 and $50 \mathrm{~g})$ and alleviative effects of salicylic acid $(0.5 \mathrm{mM})$ in wheat roots were carefully investigated in this study. Khat leaves residues stimulated hydrogen peroxide $\left(\mathrm{H}_{2} \mathrm{O}_{2}\right)$, lipid peroxidation, ascorbate (ASA), glutathione (GHS) and non-proteinthiol (NPT) contents. Salicylic acid (SA) was found to inhibit the stimulatory role of khat leaves residues on the production of $\mathrm{H}_{2} \mathrm{O}_{2}$ and lipid peroxidation in roots of wheat plants. On the other hand, SA increased ASA, GSH and NPT contents. Catalase (CAT) and ascrobate peroxide (APX) activities were increased significantly in plants growing in soil amended with khat leaves residues, while the activity of peroxidase (POD) was slightly decreased. SA additively inhibited the stimulatory effect of khat leaves residues on CAT and APX activities. In addition, the applied SA increased POD activity. Residues of khat leaves in the soil showed an inhibitory effect on pectin and cellulose fractions of roots. However, hemicellulose content of roots was stimulated. Soaking wheat caryopses in SA counteracted partially or completely the adverse effect of khat leaves residues on pectin and cellulose composition. Furthermore, the data clearly demonstrated the capability of SA treatment in retarding the stimulatory role of khat leaves residues on the production of hemicellulose in roots of wheat plants.
\end{abstract}

Keywords: Antioxidant Systems, Cell Wall, Salicylic Acid, Khat Leaves, Wheat Roots

\section{Introduction}

Secondary plant products, where studies concerning on natural substances effect occurred in plants, have been related to the allelopathy phenomenon. The term "allelopathy" refers to the plant source effect on the other target plant sample, where the released chemical compounds and the inhibitory effect have taken place [1,2]. Furthermore, allelopathic compounds are used as a chemical process to keep the plant target out of its space [3]. The allelopathic compounds can be liberated from living roots or leaves, decomposed plants can be also used as a source of these compounds, where the recorded rate of growth for the target plant can be changed. Although, a positive change in the rate of growth was reported, such change was correlated with allelopathic effects. Thus, allelopathic effects still receives a great concern though it is an old concept. In addition, the implication of allelopathy in agricultural research promoted as an interesting part of chemical ecology [2-4].

Khat (Catha edulis Forskal) belongs to the Celastraceae family, is a wild plant, cultivated in several countries including Yemen. It is sorted by the FAO as a narcotic plant [5]. People chewed the young leaves and shoots for that purpose, while the rest of the twigs are discarded.

The mechanisms of toxicity for the allelopathic compounds to some species are still unrecognized clearly. It is recorded that many phenolic compounds inhibit either seed germination of grasses and herbs, or ion uptake [6,7]. On the other hand, salicylic acid (SA) acts as a potential non-enzymatic antioxidant, and is used also as an important signal for plant response modifying to environmental stressors. Some earlier reports display exogenous SA can ameliorate the damaging effects of khat leaves residues in wheat [8], drought stress in soybean [9] and salt stress in wheat [10]. The problem of khat in Yemen is that a 
considerable area of agricultural lands that must be cultivated with several economic crops is currently replaced by khat plantation. However, our previous study [8] was constrained to exhibit the inhibitory effects of khat leaves residues on the dry mass, cell wall and proteins of wheat plants. Since no detailed investigations on the effect of khat leaves on enzymatic and non- enzymatic antioxidants of plants have been revealed so far, we have devoted the present work to study the allelopathic effect of khat leaves on some biochemical characterization of wheat roots, and to investigate the role of SA in amelioration of these effects.

\section{Materials and Methods}

\subsection{Plant Material}

Caryopses of wheat (Triticum aestivum L.) were soaked for $6 \mathrm{~h}$ in aerated water and $0.5 \mathrm{mM} \mathrm{SA}$, separately before sowed in plastic pots $(20 \mathrm{~cm}$ diameter and $15 \mathrm{~cm}$ depth) contained 2 $\mathrm{kg}$ soil (clay and sand 2:1 by volume) and lined with polyethylene bags. Detached leaves from the twigs of khat (Catha edulis Forskal) were dried at $70{ }^{\circ} \mathrm{C}$ and then ground with an electric mill to provide the residues. A 0,25 and 50 $\mathrm{g} /$ pot weight of khat powder were mixed with about $5 \mathrm{~cm}$ depth of soil in each pot. After that, caryopses were cultivated in each of 30 pots and irrigated with distilled water until the appearance of the first pair of true leaves. Three identical individuals were left in each pot and were irrigated regularly; the amount of water lost per day was compensated with distilled water to the level of field capacity (30\%). Plants were allowed to grow for 30 days under field conditions. The average prevailing climatic conditions were: temperature max. $26 \pm 2{ }^{\circ} \mathrm{C}$ and $\min .14 \pm 2{ }^{\circ} \mathrm{C}$; and relative humidity max. $58 \pm$ $3 \%$ and $\min .38 \pm 2 \%$. At the end of the experiment, plants were collected from each treatment, roots were washed thoroughly with tap water, $0.1 \mathrm{mM}$ EDTA [11] and then by distilled water for several times to get rid of soil particles and dropped dry quickly by using filter paper and absorbent tissue.

\subsection{Determination of Hydrogen Peroxide}

The hydrogen peroxide $\left(\mathrm{H}_{2} \mathrm{O}_{2}\right)$ content was determined according to [12]. Briefly, $1.0 \mathrm{~g}$ of fresh roots were homogenized in an ice bath with $5 \mathrm{ml}$ of $0.1 \%(\mathrm{w} / \mathrm{v})$ trichloroacetic acid (TCA). The homogenated solution then centrifuged at $12,000 \mathrm{rpm}$ for $15 \mathrm{~min}$ and $0.5 \mathrm{ml}$ of the supernatant was added to a solution of $0.5 \mathrm{ml}$ of $10 \mathrm{mM}$ potassium phosphate buffer $(\mathrm{pH} 7.0)$ and $1 \mathrm{ml}$ of $1 \mathrm{M}$ potassium iodide (KI). Finally, the absorbance of the supernatant was measured at $390 \mathrm{~nm}$.

\subsection{Determination of Lipid Peroxidation}

Lipid peroxidation was quantified as accumulation of the by-product malondialdenyde (MDA), according to [13]. For this, fresh tissues $(0.5 \mathrm{~g})$ were homogenized in $3 \mathrm{ml}$ of $10 \%$ TCA (trichloroacetic acid) solution. Then the homogenated solution centrifuged at $2500 \mathrm{rpm}$ for $10 \mathrm{~min}$ and the absorbance measured at $532 \mathrm{~nm}$. The supernatant was assayed for MDA concentration using an extinction coefficient of 55 $\mathrm{mM}^{-1} \mathrm{~cm}^{-1}$ and expressed as $\mu \mathrm{mol} \mathrm{g}{ }^{-1}$ fresh weight.

\subsection{Determination of Ascorbate}

The concentration of ascorbate (ASA) was measured according to the procedure reported in [14]. $0.5 \mathrm{~g}$ of fresh tissues were homogenized in 5\% (w/v) sulfosalicylic acid and then centrifuged at $10000 \mathrm{rpm}$ for $10 \mathrm{~min}$. The reaction mixture of ascorbate consisted of $2 \mathrm{ml}$ of $2 \% \mathrm{w} / \mathrm{v}$ sodium-molybdate, $2 \mathrm{ml}$ of $0.15 \mathrm{mM} \mathrm{NH}_{2} \mathrm{SO}_{4}, 1 \mathrm{ml}$ of $1.5 \mathrm{mM}$ $\mathrm{NaHPO}_{4}$ and $1 \mathrm{ml}$ tissue extract. It was incubated at $60{ }^{\circ} \mathrm{C}$ in water bath for $40 \mathrm{~min}$, cold and centrifuged again at $3000 \mathrm{rpm}$ for $10 \mathrm{~min}$. The absorbance was measured at $660 \mathrm{~nm}$.

\subsection{Determination of Glutathione}

Glutathione (GSH) was quantified fluorometrically according to [15]. Fresh roots $(0.5 \mathrm{~g})$ were ground and dissolved in a mixture of $1 \mathrm{ml}$ of $25 \% . \mathrm{H}_{3} \mathrm{PO}_{4}$ and $3 \mathrm{ml}$ of 0.1 $\mathrm{M}$ sodium phosphate-EDTA buffer ( $\mathrm{pH}$ 8.0). The homogenate was then centrifuged at $10000 \mathrm{rpm}$ for $20 \mathrm{~min}$, and the supernatant was further diluted five times with sodium phosphate-EDTA buffer ( $\mathrm{pH}$ 8.0). The final assay mixture (2.0 $\mathrm{ml})$ contained $100 \mu \mathrm{l}$ of the diluted supernatant, $1.8 \mathrm{ml}$ of phosphate-EDTA-buffer and $100 \mu$ l of O-phthalaldehyde (1 $\mathrm{mg} \mathrm{ml} \mathrm{m}^{-1}$ ). After thorough mixing and incubation at room temperature for $15 \mathrm{~min}$, the solution finally transferred to a quartz cuvette and the fluorescence at $420 \mathrm{~nm}$ was measured after excitation at $350 \mathrm{~nm}$.

\subsection{Determination of Non-Protein Thiol}

The concentration of non-protein thiol (NPT) was determined by measuring the absorbance at $412 \mathrm{~nm}$ following the method recorded in [16]. For this, fresh roots $(0.5 \mathrm{~g})$ in 5 $\mathrm{ml}$ of potassium phosphate buffer ( $\mathrm{pH} 8.0$ ) were homogenized in an ice bath, and then centrifuged at $10000 \mathrm{rpm}$ for $20 \mathrm{~min}$. The supernatant was used for NPT assay using 5,5-dithio-2,2-dinitrobezoic acid as a reagent.

\subsection{Antioxidative Enzyme Assay}

The CAT activity was assayed using the method described in [17]. The assay mixture in a total volume of $3.0 \mathrm{ml}$ contained $2.8 \mathrm{ml}$ of $50 \mathrm{mM} \mathrm{NaH} \mathrm{PO}_{4}-\mathrm{Na}_{2} \mathrm{HPO}_{4}$ buffer $(\mathrm{pH}$ 7.0), $19 \mathrm{mM} \mathrm{H}_{2} \mathrm{O}_{2}$ and $0.2 \mathrm{ml}$ of enzyme extract. The activity was assayed by monitoring the decrease in the absorbance at $240 \mathrm{~nm}$ as a consequence of $\mathrm{H}_{2} \mathrm{O}_{2}$ consumption. The activity was calculated as the decrease of absorbance $(\Delta \mathrm{E}) \mathrm{min}^{-1} \mathrm{~g}^{-1}$ fresh weight. The POD activity was assayed following the method described in [18]. Briefly, the assay mixture contained $2.95 \mathrm{ml}$ of $100 \mathrm{mM} \mathrm{NaH} \mathrm{PO}_{4}-\mathrm{Na}_{2} \mathrm{HPO}_{4}$ buffer (pH 6.0), 2 $\mathrm{mM} \mathrm{H}_{2} \mathrm{O}_{2}, 9 \mathrm{mM}$ guaiacol and $0.05 \mathrm{ml}$ enzyme extract in a total volume of $3.0 \mathrm{ml}$. Changes in the absorbance of the brown guaiacol at $460 \mathrm{~nm}$ in the presence of $\mathrm{H}_{2} \mathrm{O}_{2}$ were recorded for calculating POD activity. Enzyme activity was calculated as the increase of absorbance $(\Delta \mathrm{E}) \mathrm{min}^{-1} \mathrm{~g}^{-1}$ fresh 
weight. The APX activity was assayed by using the method described in [19]. The reaction mixture contained $50 \mathrm{mM}$ potassium-phosphate buffer, $0.5 \mathrm{mM}$ of L-ascorbate (ASA), $0.1 \mathrm{mM} \mathrm{H} \mathrm{H}_{2} \mathrm{O}_{2}$ and the enzyme extract. $\mathrm{H}_{2} \mathrm{O}_{2}$-dependent oxidation of ASA was followed by a decrease in absorbance at $290 \mathrm{~nm}$. APX activity was expressed as the absorbance decrease $(\Delta \mathrm{E}) \mathrm{min}^{-1} \mathrm{~g}^{-1}$ fresh weight. Cell wall fractionation was conducted essentially according to $[20,21]$. Tissue powder sample then extracted in $0.5 \%$ ammonium oxalate-oxalic acid $\left(90{ }^{\circ} \mathrm{C}\right.$ for $24 \mathrm{~h}$ ) for pectin, $17.5 \% \mathrm{NaOH}$ for hemicelluloses, and in $72 \% \mathrm{H}_{2} \mathrm{SO}_{4}$ (with $15 \mathrm{~min}$ autoclaving) for cellulose extraction. Contents of wall polysaccharides finally determined by the anthrone sulfuric acid reagent using glucose as standard [22]. The experiment was repeated independently five times ( 5 replicates / treatment).

\subsection{Statistical Analysis}

Standard procedure of one-way ANOVA was used to analyze data, and the means were separated by Turkey's test. The differences indicated at $\mathrm{p} \leq 0.05$ significance value.

\section{Results and Discussion}

Hydrogen peroxide $\left(\mathrm{H}_{2} \mathrm{O}_{2}\right)$ produced during environmental stresses may act both as an agent of oxidative stress and a regulator of various antioxidant enzymes involved in the amelioration of oxidative stress [23]. $\mathrm{H}_{2} \mathrm{O}_{2}$ induced increase in antioxidant enzymes [24] have also reported earlier. In the present study, $\mathrm{H}_{2} \mathrm{O}_{2}$ content was remarkably enhanced by khat leaves residues (Fig. 1A). A significant increase by $47.50 \%$ and $75.12 \%$ was observed in $\mathrm{H}_{2} \mathrm{O}_{2}$ content at 25 and $50 \mathrm{~g}$ of khat leaves residues, respectively in comparison to unstressed ones. It has been found that the increase of $\mathrm{H}_{2} \mathrm{O}_{2}$ production in wheat plants is associated with the activation of the ROS-producing enzymes and the inactivation of antioxidant enzymes. The enhanced $\mathrm{H}_{2} \mathrm{O}_{2}$ levels detected in khat leaves stress should be indirectly originated from a decreased $\mathrm{H}_{2} \mathrm{O}_{2}$-scavenging rate and / or an increased $\mathrm{H}_{2} \mathrm{O}_{2}$ production by cell enzymatic and non-enzymatic processes. Under non-stress conditions, added SA caused significant decreases in $\mathrm{H}_{2} \mathrm{O}_{2}$ content in roots wheat by $25.26 \%$ (Fig. 1A). Pretreatment with SA significantly decreased $\mathrm{H}_{2} \mathrm{O}_{2}$ content in roots wheat by $43.56 \%$ and $31.93 \%$ at 25 and $50 \mathrm{~g}$ of khat leaves residues, respectively.

MDA is one of the end products which are produced as a result of lipid production damage by free radicals. Lipid production level as indicated by accumulated MDA. In the present study, MDA level increased significantly in the roots of wheat under khat leaves stress (Fig. 1B). It was found that maximum MDA level increased by $69.59 \%$ and $107.73 \%$ in 25 and $50 \mathrm{~g}$ of khat leaves residues as compared to control. This suggests a khat stress induced membrane injury, which may be due to changes in the membrane lipids or protein or both. It is interesting to note that the increase in lipid peroxidation might be due to the capability of endogenous antioxidants to scavenge all ROS resulting from khat stress. The applied SA was generally effective in antagonizing partially or completely the stimulatory effect of khat leaves stress on MDA level in wheat roots (Fig. 1B). The maximum decrease in MDA level was $34.07 \%$ and $43.08 \%$ of 25 and $50 \mathrm{~g}$ of khat leaves residues at $0.5 \mathrm{mM} \mathrm{SA}$, respectively (Fig. 1B). Under non-stress conditions, MDA was decreased by $39.78 \%$ under SA treatment in the roots wheat. However, SA decreases the content of lipid peroxidation by inhibiting production of hydroxyl radical. The beneficial effect of SA could be attributed to modified compartmentalization, and increased activities of defense mechanisms such as antioxidant enzymes which could be involved in lowering khat leaves stress.
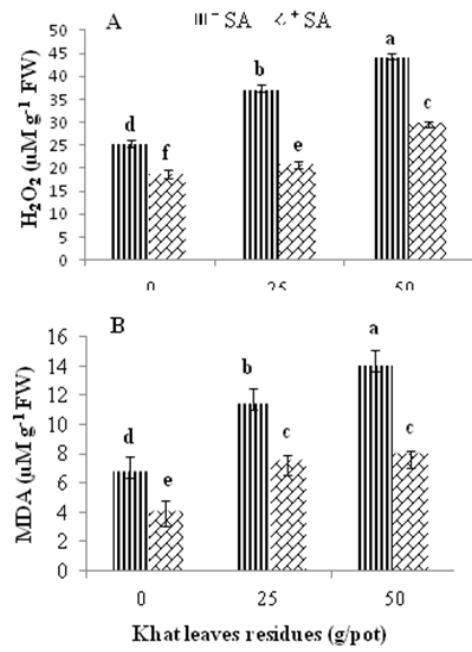

Figure 1. Effect of khat leaves residues and $\mathrm{SA}$ on $\mathrm{H}_{2} \mathrm{O}_{2}(\mathrm{~A})$ and $M D A$ (B) of wheat roots. Values are means $\pm S D(n=5)$. Bare with the same letters are not significantly different at $p \leq 0.05$.
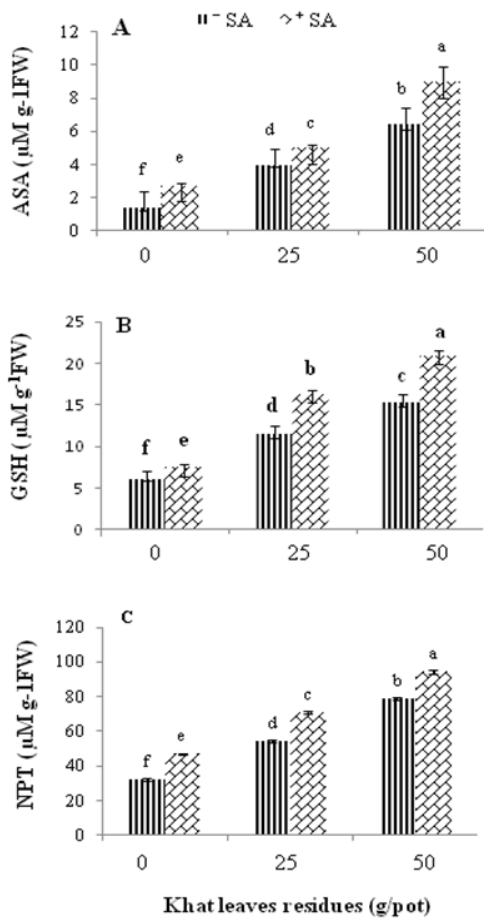

Figure 2. Effect of khat leaves residues and SA on ASA (A), GSH (B) and NPT (C) of wheat roots. Values are means $\pm S D(n=5)$. Bare with the same letters are not significantly different at $p \leq 0.05$. 
ASA was increased by 2.80 and 4.53 folds in wheat roots exposed to khat leaves treatment at 25 and $50 \mathrm{~g}$, respectively in respect to control (Fig. 2A). The importance of ASA accumulation could probably be explained by its involvement in non-enzymatic antioxidative activity in plant roots with a higher level of $\mathrm{H}_{2} \mathrm{O}_{2}$ [25]. SA pre-application, however, increased ASA concentration by 1.26 and 1.39 folds compared to 25 and $50 \mathrm{~g}$ of khat leaves residues, respectively (Fig. 2A). SA alone also elevated ASA concentration by 1.96 fold in roots wheat.

GSH is a major non-enzymatic scavenger of ROS due to its unique structural properties, broader redox potential, abundance and wide distribution in plants. In the present study, the addition of khat leaves residues consistently increased GSH content compared with the control (Fig. 2B). Compared to control, GSH content showed approximately $90.05 \%$ and $151.71 \%$ increased in 25 and $50 \mathrm{~g}$ of khat leaves residues, respectively. This significant GSH accumulation indicates that the ASC-GSH cycle might not be involved effectively in the removal of $\mathrm{H}_{2} \mathrm{O}_{2}$. However, the increased level of GSH under such a stress is likely attributed to the induced transcription of the genes responsible for GSH biosynthesis, such as $\gamma$-glutamylcysteine synthetase, glutathione synthetase and glutathione reductase [26]. SA alone increased GSH content by $23.57 \%$. SA pretreatment initially increased GSH content in roots wheat by $41.22 \%$ and $37.57 \%$ prior to 25 and $50 \mathrm{~g}$ of khat leaves residues, respectively (Fig. 2B).

NPT level showed approximately $69.30 \%$ and $145.32 \%$ increased in 25 and $50 \mathrm{~g}$ of khat leaves residues (Fig. 2C). The SA pretreatment initially stimulated NPT level in roots wheat by $30.68 \%$ and $19.79 \%$ at 25 and $50 \mathrm{~g}$ of khat leaves residues (Fig. 2C). SA alone showed remarkable increase in the level of NPT by $46.62 \%$.

CAT activity in wheat roots was significantly increased by $115.25 \%$ and $217.09 \%$ at 25 and $50 \mathrm{~g}$ of khat leaves residues, respectively compared with control (Fig. 3A). SA pretreatment significantly decreased CAT activity in khat leaves residues wheat roots compared with that of khat leaves alone treatment (Fig. 3A). The maximum decrease in CAT activity by SA was reached $46.61 \%$ and $51.96 \%$ at 25 and $50 \mathrm{~g}$ of khat leaves residues, respectively. SA pretreatment alone also significantly decreased CAT activity by $40.35 \%$.

Khat leaves residues significantly decreased POD activity in wheat roots by approximately $45.98 \%$ and $64.51 \%$ at 25 and $50 \mathrm{~g}$ of khat leaves residues, respectively (Fig. 3B). The decreased POD activity coupled with the expected increase of CAT activity indicates the POD has a lower elevated affinity to $\mathrm{H}_{2} \mathrm{O}_{2}$ than CAT. In addition, POD may be involved in the oxidation of various molecules, such as $\mathrm{NAD}(\mathrm{P}) \mathrm{H}$ through which $\mathrm{H}_{2} \mathrm{O}_{2}$ is further produced [27]. SA pretreatment alone also decreased POD activity by $25.57 \%$. The application of SA significantly increased POD activity at low and high levels of khat levels residues (Fig. 3B). The ameliorative effects of SA on khat leaves-induced reduction in POD activity were $47.12 \%$ and $75.63 \%$ at 25 and $50 \mathrm{~g}$ of khat leaves residues, respectively.

APX activity showed a significant increase by $72.82 \%$ and
$172.91 \%$ after exposure to 25 and $50 \mathrm{~g}$ of khat leaves residues, respectively (Fig. 3C). This reflects the defensive role of APX in ascrobate-glutathion cycle in the reduction of $\mathrm{H}_{2} \mathrm{O}_{2}$ to water and oxygen during khat stress. The applied SA was generally effective in antagonizing partially or completely the stimulatory effect of khat leaves stress on APX activity in roots of test plants (Fig. 3C). The maximum decrease in APX activity by SA treatment was $32.18 \% 51.26 \%$ and $54.34 \%$ under 0,25 and $50 \mathrm{~g}$ of khat leaves residues, respectively.
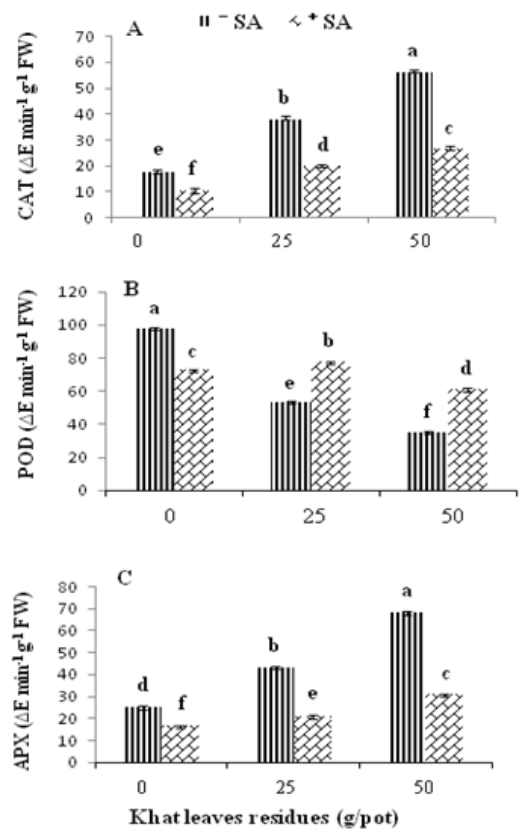

Figure 3. Effect of khat leaves residues and SA on $C A T(A), P O D(B)$ and $A P X$ (C) of wheat roots. Values are means $\pm S D(n=5)$. Bare with the same letters are not significantly different at $p \leq 0.05$.
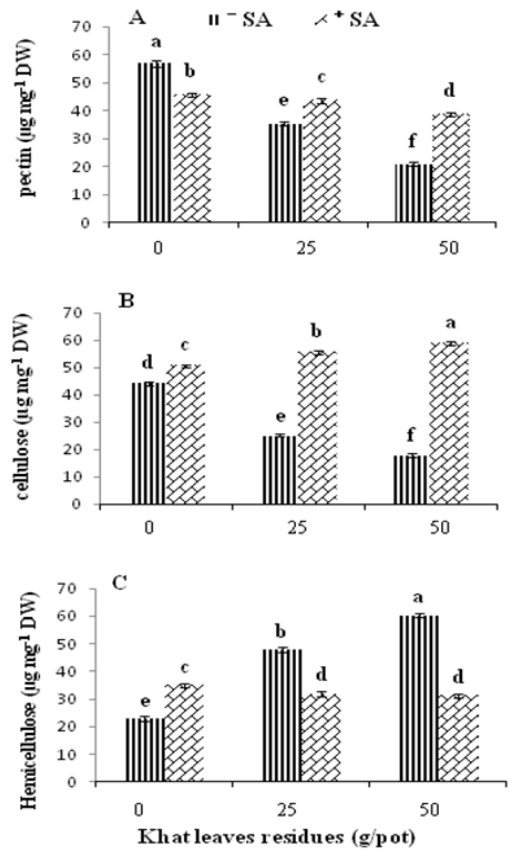

Figure 4. Effect of khat leaves residues and SA on pectin (A), cellulose (B) and hemicellulose $(C)$ of wheat roots. Values are means $\pm S D(n=5)$. Bare with the same letters are not significantly different at $p \leq 0.05$. 
Cell wall metabolism is an important component in plant growth, not only because it represents a large proportions of the cell biomass, but also because determining wall extensibility for cell enlargement [28]. In this investigation, pectin, cellulose and hemicellulose were determined in roots wheat (Fig. 4A, 4B and 4C). The pectin and cellulose fractions of roots were significantly decreased by increasing khat leaves residues in the soil (Fig. 4A and 4B). The reduction in pectin and cellulose fractions were $38.58 \%, 63.30 \%, 43.48 \%$ and $59.70 \%$ at 25 and $50 \mathrm{~g}$ of khat leaves residues, respectively. Application of SA allayed the negative effect of khat leaves residues on pectin and cellulose fractions (Fig. 4A and 4B). The maximum increase in pectin and cellulose fractions by SA treatment were reached $25.52 \%, 86.41 \%, 124.47 \%$ and $245.78 \%$ at 25 and 50 $\mathrm{g}$ of khat leaves residues, respectively. On the other side, hemicellulose content was stimulated by the amount of khat leaves added to the soil (Fig. 4C). The increase in hemicellulose content induced by khat leaves treatment was $110.15 \%$ and $164.46 \%$ at 25 and $50 \mathrm{~g}$ of khat leaves residues, respectively. The applied SA inhibited the stimulatory role of khat leaves on the production of hemicellulose in roots (Fig. 4C). The maximum decrease in hemicellulose content by SA treatment was $33.28 \%$ and $48.13 \%$ at 25 and $50 \mathrm{~g}$ of khat leaves residues, respectively.

In roots of control wheat plants the wall polysaccharides could be arranged as follows: pectin $>$ cellulose > hemicellulose. This arrangement has been changed by khat leaves residues to be as follows: hemicellulose $>$ pectin $>$ cellulose, i.e. khat leaves residues shifted the hemicellulose to be higher than cellulose. Soaking of wheat caryopses in SA such arrangement was changed to be cellulose $>$ pectin $>$ hemicellulose. This is in a good agreement with our previous work on wheat plants [8].

\section{Conclusions}

In conclusion, allelopathic effects of khat leaves residues in wheat roots were revealed by stimulated production of $\mathrm{H}_{2} \mathrm{O}_{2}$ and lipid peroxidation, increased activities of enzymatic antioxidants (CAT and APX), and increased contents of nonenzymatic antioxidants (ASA, GHS and NPT). However, the SA pretreatment inhibited the stimulatory role of khat leaves residues on the production of $\mathrm{H}_{2} \mathrm{O}_{2}$, lipid peroxidation, and activities of CAT and APX. In addition, the alleviative effects of SA were clearly evident in retarding the inhibitory effect of khat leaves residues on pectin and cellulose production, meanwhile hemicellulose was degraded.

\section{References}

[1] Mubeen, K., Ather Nadem, M., Tanveer, A., and Zahir, Z.A. 2011. Allelopathic effect of aqueous extracts of weeds on the germination and seedling growth of rice (Oryza sativa L.). Pak. J. Life Soc. 9 (1):7-12.

[2] Weir, T.L., Park, S. and Vivanco, J.M. 2004. Biochemical and physiological mechanisms mediated by allelochemicals. Plant
Biol. 7:472-479.

[3] Weston, L.A. and Duke, S.O. 2003. Weed and crop allelopathy. Plant Sci. 22:367-389.

[4] Reigosa, M.J. Pedrol, N. Sanchez-Moreiras, A.M. and Gonzales, L. 2002. Stress and allelopathy. In: Reigosa, M.J. and Pedrol, N. (Eds.): Allelopathy from Molecules to Ecosystems. Science Publishers, Enfield.

[5] FAO. 1980. Catha edulis (khat), Bull on Narcotics Vol. XXX. Food and Agriculture Organization of the United Nations, Roma.

[6] Li, Z. Wang, Q. Ruan, X. Pan, C. and Jiang, D. 2010. Phenolics and allelopathy. Molecules. 15: 8933-8952.

[7] Përez-Corona, M.E. de lasheras, P. and Väzquez de Aldana, B.R. 2013. Allelopathic potential of invasive Ulmuspumila on understory plant species. Allelopathy J. 32:101-112.

[8] Al-Hakimi, A.M.A. 2008. Effect of salicylic acid on biochemical changes in wheat plants under khat leaves residues. Plant Soil Environ., 54:288-293.

[9] Al-Hakimi, A.M.A. 2006. Counteraction of drought stress on soybean plants by seed soaking in salicylic acid. J. Bot. 2:421-426.

[10] Al-Hakimi, A.M.A. and Hamada, A.M. 2001. Counteraction of salinity stress on wheat plants by grain soaking in ascorbic acid, thiamin or sodium salicylate. Biol. Plant. 44:253-261.

[11] Allen, S.E. 1989. Chemical Analysis of Ecological Materials. Blackwell Scientific Publications, Oxford.

[12] Velikova, V. Yordanov, I. and Edreva, A. 2000. Oxidative stress and some antioxidant systems in acid rain treated bean plants, protective role of exogenous polyamines. Plant Sci. 151:59-66.

[13] MadhavaRao, K.V. and Sresty, T.V.S. 2000. Antioxidative parameters in the seedlings of pigeon pea (Cajanus cajan $\mathrm{L}$. Millspaugh) in response to $\mathrm{Zn}$ and $\mathrm{Ni}$ stresses. Plant Sci. 157:113-128.

[14] Kampfenkel, K. Van Montagu, M. and Inzé, D. 1994. Extraction and determination of ascorbate and dehydroascorbate from plant tissue. Anal Biochem. 225:165-167.

[15] Hissin, P.J. and Hilf, R. 1976. A fluorometric method for determination of oxidized and reduced glutathione in tissues. Anal. Bioche. 74:214-226.

[16] Metwally, A. Finkemeier, I. Georgi, M. and Dietz, K.J. 2003. Salicylic acid alleviates the cadmium toxicity in barley seedling. Plant Physio. 132:272-281.

[17] Rout, N.P. and Shaw, B.P. 2001. Salt tolerance in aquatic macrophytes: Possible involvement of the antioxidative enzymes. Plant Sci. 160:415-423.

[18] Ghanati, F., Morita, A. and Yakota, H. 2002. Induction of suberin and increase of liginin content by excess boron in tobacco cell. Soil Sci. Plant Nutr. 48:357-364.

[19] Hassan, M.J., Shao, G.S. and Zhang, G.P. 2005. Influence of cadmium toxicity on growth and antioxidant enzyme activity in rice cultivars with different grain cadmium accumulation. J. Plant Nutr. 28:1259-1270. 
[20] Selvendran, R.R. and $\mathrm{O}^{\prime}$ Neill, M.A. 2006. Isolation and analysis of cell wall from plant material. Methods of Biochem. Anala. 32:125-153.

[21] Acebes, J.L. and Zarra, I. 1992. Cell wall glyconases and their activity against the hemicelluloses from pine hypocotyles. Physiol. Plant. 86:433-438.

[22] Whistler, R.L., Wolform, M.L., Bemiller, N. and Shafizadeh, F. 1962. Anthron colorimetric method. In: Methods in carbohydrate. Chemistry. Academic Press, New York, London. $1: 384$.

[23] Desikan, R. Neills, J. and Hancock, J.T. 2000. Hydrogen peroxide-induced gen expression in Arabidopsis Thaliana. Free Radical Biol. Med. 28 (5):773-778.

[24] Sairam, R.K. and Srivastava, G.C. 2000. Induction of oxidative stress and antioxidant activity by hydrogen peroxide treatment in tolerant and susceptible wheat genotype. Biol. Plant. 42:381-386.
[25] Schützendübel, A. Schwanz, P. Teichmann, T. Gross, K. Langenfeld-Heyser, R. Godbold, D.L. and Polle, A. 2001.Cadmium-induced changes in antioxidative systems, hydrogen peroxide content, and differentiation in scots pine roots. Plant Physiol.127: 887-898.

[26] Mishra, S. Srivastava, S. Tripathi, R.D. Govindarajan, R. Kuriakose, S.V. and Prasad, M.N.V. 2006. Phytochelatin synthesis and response of antioxidants during cadmium in (Bacopa monnieri L.). Plant Physiol. And Biochem. 44: 25-37.

[27] Bestwick, C.S. Brown. I.R. and Mansfield, S.W. 1998. Localized changes in peroxidase activity accompany hydrogen peroxide generation during the development of a non-host hypersensitive reaction in lettuce. Plant Physiol. 118: 1067-1078.

[28] Hamada, A.M. 2001. The biochemical adaptive strategies for drought-salt resistance of wheat plants. Rostlinna' Viroba. 47:247-252. 